\title{
PAH-degradation by Paenibacillus spp. and description of Paenibacillus naphthalenovorans sp. nov., a naphthalene-degrading bacterium from the rhizosphere of salt marsh plants
}

1 Biotechnology Center for Agriculture and the Environment, Foran Hall, Cook College, Rutgers University, 59 Dudley Road, New Brunswick, NJ 08901-8520, USA

2 Bioscience Division, Environmental Molecular Biology Group, M888, Los Alamos National Laboratory, Los Alamos, NM 87545, USA

3 Department of Biochemistry and Microbiology, Lipman Hall, Cook College, Rutgers University, 76 Lipman Drive, New Brunswick, NJ 08901-8525, USA

\author{
L. L. Daane, ${ }^{1} \dagger$ I. Harjono, ${ }^{1}$ S. M. Barns, ${ }^{2}$ L. A. Launen, ${ }^{1,3}$ N. J. Palleroni ${ }^{1,3}$ \\ and M. M. Häggblom ${ }^{1,3}$
}

\begin{abstract}
Author for correspondence: Max Häggblom. Tel: +1 7329329763 ext. 326. Fax: +1 7329328965. e-mail: haggblom@aesop.rutgers.edu
\end{abstract}

\begin{abstract}
Bacteria belonging to the genus Paenibacillus were isolated by enrichment from petroleum-hydrocarbon-contaminated sediment and salt marsh rhizosphere using either naphthalene or phenanthrene as the sole carbon source, and were characterized using phenotypic, morphological and molecular techniques. The isolates were grouped by their colony morphologies and polyaromatic hydrocarbon-degradation patterns. Phenanthrene-degrading isolates produced mottled colonies on solid media and were identified as $P$. validus by fatty acid methyl ester and 16S rRNA gene sequence analyses. In contrast, the naphthalene-degrading isolates with mucoid colony morphology were distantly related to Paenibacillus validus, according to fatty acid methyl ester and 16S rRNA gene sequence analyses. The predominant fatty acids of

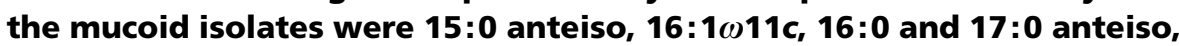
constituting, on average, 50.5, 12.0, 11.2 and $6.5 \%$ of the total, respectively. The $G+C$ contents of their DNA ranged from 47 to $52 \mathrm{~mol} \%$. The 165 rDNA sequence analysis revealed the highest $(\leq 94 \%)$ similarity to $P$. validus. In addition, phylogenetic analyses based on 16S rDNA sequences showed that the mucoid isolates formed a distinct cluster within Paenibacillus. DNA-DNA hybridization experiments showed only a $6 \%$ DNA similarity between the type strain of $P$. validus and mucoid strain PR-N1. On the basis of the morphological, phenotypic and molecular data, the naphthalene-degrading isolates merit classification as a new Paenibacillus species, for which the name Paenibacillus naphthalenovorans sp. nov. is proposed, with PR-N1' ( = ATCC BAA-206 ${ }^{\top}=$ DSM $14203^{\top}$ ) as the type strain.
\end{abstract}

Keywords: Paenibacillus, rhizosphere, polycyclic aromatic hydrocarbons

\section{INTRODUCTION}

In 1991, Ash et al., determined the phylogenetic structure of the genus Bacillus by using the smallsubunit rRNA sequences of 51 species. The study revealed five phylogenetically distinct clusters, group 3 bacilli being separated as the new genus Paenibacillus (Ash et al., 1993). Since 1993, the genus Paenibacillus

† Present address: Avon Products, Inc., Avon Place, Suffern, NY 109015605, USA.

Abbreviations: ED, Euclidean distance; FAME, fatty acid methyl ester; $\mathrm{PAH}$, polyaromatic hydrocarbon. has grown from 11 species to over 26 species. Sporogenesis enables Bacillus, Paenibacillus and related organisms to withstand environmentally stressful conditions, allowing long-term survival and making them virtually ubiquitous (Claus \& Berkeley, 1986). Paenibacillus species have been isolated from a wide variety of sources including soil, water, the plant rhizosphere, plant materials, food, fodder, faeces and diseased insect larvae (Alexander \& Priest, 1989; Claus \& Berkeley, 1986; Kanzawa et al., 1995; Montefusco et al., 1993; Nakamura, 1984, 1987; Seldin et al., 1984; Shida et al., 1997b; Yoon et al., 1998).

We have isolated a variety of Gram-positive and 
Gram-negative polyaromatic hydrocarbon (PAH)degrading bacteria from estuarine sediment and the rhizospheres of salt marsh plants (Distichlis spicata, Juncus gerardi, Spartina alterniflora and Sporobolus airoides). In the process, we have isolated endosporeforming bacteria by using a pasteurization enrichment technique (Daane et al., 2001). Initial assignment of the isolates to the genus Paenibacillus was based on their fatty acid methyl ester (FAME) profiles. These isolates were further grouped by their colony morphologies and PAH-degradation profiles. Isolates exhibiting non-mucoid, mottled colonies were tentatively identified as Paenibacillus validus, while isolates forming mucoid colonies were judged to be distant relatives of P. validus, Paenibacillus alvei and Paenibacillus pabuli. In the present investigation, we used morphological, phenotypic and molecular techniques to assess the taxonomic position of the mucoid Paenibacillus isolates. We have determined that the mucoid group is distinct from previously identified species of the genus Paenibacillus, and we propose the new species Paenibacillus naphthalenovorans.

\section{METHODS}

Bacterial isolates and growth conditions. Spore-forming PAH-degrading bacteria were obtained from pasteurized $\left(80{ }^{\circ} \mathrm{C}, \quad 10 \mathrm{~min}\right)$, petroleum-hydrocarbon-contaminated estuarine sediment and salt marsh plant rhizospheres by aerobic enrichment using either naphthalene, phenanthrene or biphenyl as the sole carbon source (Daane et al., 2001). The tentatively identified Paenibacillus isolates separated into two distinct morphological groups: one formed mucoidal colonies, and the other did not (Table 1). The colony morphologies were maintained over repeated subculturing as well as reculturing from frozen stocks. The type strains of the following species were purchased from the American Type Culture Collection (ATCC, Manassas, VA, USA) and used as controls in the phenotypic and whole-cell fatty acid analyses: P. alvei ATCC 6344, P. pabuli ATCC 43899, Paenibacillus polymyxa ATCC 842 and Paenibacillus validus ATCC $43897^{\mathrm{T}}$.

Bacterial strains were grown on trypticase soy (Beckton Dickinson) agar (TSA) plates for phenotypic, phylogenetic and FAME analyses. Mineral salts basal (MSB) medium (Stanier et al., 1966), containing 2\% (w/v) Noble agar (Difco) and naphthalene, biphenyl or phenanthrene as the carbon source was used routinely for maintaining the PAHdegrading phenotype. The bacteria were routinely grown aerobically at $30^{\circ} \mathrm{C}$ except where indicated otherwise. Isolates were maintained at $4{ }^{\circ} \mathrm{C}$, and were kept in $50 \%$ (v/v) glycerol at $-80^{\circ} \mathrm{C}$ for long-term storage.

FAME analysis. Whole-cell fatty acid (FAME) analyses were performed on all of the ATCC type strains and PAHdegrading isolates by growing the cells at $28^{\circ} \mathrm{C}$ for $24 \mathrm{~h}$ on TSA plates. Cellular fatty acids were saponified, methylated and extracted and then analysed by GC by following the procedures given for the Sherlock Microbial Identification System (MIDI). Identification and comparison were made using the Aerobe (TSBA version 3.9) database of the Sherlock Microbial Identification System. The DENDROGRAM program resident in the MIDI software package was used to construct unweighted pair matching based on fatty acid data.
Table 1. Polyaromatic hydrocarbon (PAH)-degrading spore-forming bacteria isolated by pasteurized enrichment from contaminated estuarine sediment and plant rhizospheres

\begin{tabular}{|c|c|c|}
\hline Isolate* & Source $\dagger$ & Enrichment substrate \\
\hline \multicolumn{3}{|l|}{ Mucoid } \\
\hline $\mathrm{PR}-\mathrm{N} 1^{\mathrm{T}}$ & Spartina alterniflora & Naphthalene \\
\hline PR-N2 & Spartina alterniflora & Naphthalene \\
\hline PR-N5 & Spartina alterniflora & Naphthalene \\
\hline PR-N11 & Spartina alterniflora & Naphthalene \\
\hline PR-N12 & Spartina alterniflora & Naphthalene \\
\hline PR-N16 & Spartina alterniflora & Naphthalene \\
\hline PS-N1 & Estuarine sediment & Naphthalene \\
\hline PS-N6 & Estuarine sediment & Naphthalene \\
\hline SA-N1 & Sporobolus airoides & Naphthalene \\
\hline \multicolumn{3}{|c|}{ Non-mucoid } \\
\hline PR-N3 & Spartina alterniflora & Naphthalene \\
\hline PR-N4 & Spartina alterniflora & Naphthalene \\
\hline PR-N13 & Spartina alterniflora & Naphthalene \\
\hline PR-N19 & Spartina alterniflora & Naphthalene \\
\hline PR-N20 & Spartina alterniflora & Naphthalene \\
\hline PR-N21 & Spartina alterniflora & Naphthalene \\
\hline PR-N22 & Spartina alterniflora & Naphthalene \\
\hline DS-N1 & Distichlis spicata & Naphthalene \\
\hline DS-N2 & Distichlis spicata & Naphthalene \\
\hline DS-N3 & Distichlis spicata & Naphthalene \\
\hline JG-N1 & Juncus gerardi & Naphthalene \\
\hline $\mathrm{JG}-\mathrm{N} 2$ & Juncus gerardi & Naphthalene \\
\hline $\mathrm{JG}-\mathrm{N} 3$ & Juncus gerardi & Naphthalene \\
\hline PR-B1 & Spartina alterniflora & Biphenyl \\
\hline PR-B2 & Spartina alterniflora & Biphenyl \\
\hline PR-P1 & Spartina alterniflora & Phenanthrene \\
\hline PR-P2 & Spartina alterniflora & Phenanthrene \\
\hline PR-P6 & Spartina alterniflora & Phenanthrene \\
\hline PR-P9 & Spartina alterniflora & Phenanthrene \\
\hline PR-P10 & Spartina alterniflora & Phenanthrene \\
\hline PR-P11 & Spartina alterniflora & Phenanthrene \\
\hline PR-P13 & Spartina alterniflora & Phenanthrene \\
\hline
\end{tabular}

* Mucoid and non-mucoid refer to colony morphologies when grown on solid media.

$\dagger$ Estuarine sediment and Spartina alterniflora were obtained from Piles Creek, Linden, NJ, USA. Distichlis spicata, Juncus gerardi and Sporobolus airoides were obtained from The University of Delaware Marine Station, Lewes, DE, USA.

Morphological and phenotypic characterizations. The morphology of the ATCC type strains and PAH-degrading isolates was observed using a phase-contrast microscope. Trypticase soy broth $(2 \mathrm{ml})$ was inoculated with the bacteria being tested and was incubated at $37^{\circ} \mathrm{C}$ on a rotary wheel. Motility and morphology were observed at 24, 48 and $72 \mathrm{~h}$ in drops of culture placed onto $1 \%(\mathrm{w} / \mathrm{v})$ agarose-coated and -uncoated glass slides. The agarose coating enabled more detailed examination of motile cells. Flagella were stained according to the method of Leifson (1951). Photomicrographs were taken using a Leitz Planfluotar oil immersion lens (NA 1.32).

The bacterial isolates and type strains were phenotypically 
characterized by using the API $20 \mathrm{E}$ and $50 \mathrm{CH}$ system tests (bioMérieux Vitek) as described by Logan \& Berkeley (1984). Other phenotypic tests included catalase activity, starch and casein hydrolyses, and the effects of temperature, anaerobiosis and salinity on growth (Smibert \& Krieg, 1994). For testing individual aromatic growth substrates, MSB agar medium, containing one of the following aromatic compounds, was used: naphthalene, phenanthrene, biphenyl, phthalate, gentisate, $o$-, $m$ - and $p$-hydroxybenzoate or benzoate (minimum $98 \%$ pure; Aldrich). Naphthalene and biphenyl were added in the vapour phase as crystals in the Petri-dish lid. Phenanthrene was added as a $2 \%(\mathrm{w} / \mathrm{v})$ Noble agar overlayer onto MSB agar plates at a final concentration of $1 \mathrm{mg} \mathrm{ml}^{-1}(\sim 5.6 \mathrm{mM})$. The remaining organic acids were added from filter-sterilized stock solutions to autoclaved molten MSB agar medium at final concentrations ranging from 5 to $10 \mathrm{mM}$.

DNA preparation. Total genomic DNA for phylogenetic and $\mathrm{G}+\mathrm{C}$-content analyses was isolated from bacterial cells grown on TSA plates for $48 \mathrm{~h}$ using a modification of a method described by Wilson (1994). The collected bacterial pellets were pretreated with lysozyme $\left(2.5 \mathrm{mg} \mathrm{ml}^{-1}\right)$ for $1 \mathrm{~h}$ at $37^{\circ} \mathrm{C}$. The preparation and labelling of reference strain DNA for hybridization experiments were carried out as described by Song et al. (1998). DNA was diluted in $0 \cdot 1 \times$ standard saline citrate $(1 \times$ standard saline citrate is $0.15 \mathrm{M}$ sodium citrate, $0 \cdot 15 \mathrm{M} \mathrm{NaCl}, \mathrm{pH} \mathrm{7.0)}$ and examined for purity spectrophotometrically at 260 and $280 \mathrm{~nm}$. The reading at $260 \mathrm{~nm}$ was used for quantitative estimation, by assuming an absorption coefficient of 20 .

Phylogenetic analysis of 16S rDNA sequences. The $16 \mathrm{~S}$ rDNA was PCR-amplified as described by Daane et al. (2001), using the eubacterial primers $27 \mathrm{f}$ and 1522 r (Johnson, 1994b). Five microlitres of each reaction was run on a $1 \%$ agarose gel, and the DNA was visualized by UV illumination following staining with ethidium bromide. The amplified PCR products were purified using the QIAquick PCR purification kit (Qiagen) according to the manufacturer's instructions. DNA sequences were determined directly from the purified PCR products with automated fluorescent Taq cycle sequencing using an ABI 373A sequencer (Applied Biosystems). Approximately $100 \mathrm{ng}$ purified DNA was used for one automated fluorescent sequencing reaction. The primers for sequencing used in this study were $27 \mathrm{f}, 704 \mathrm{f}$, 926f, 1242f, 321r, 685r, 907r, 1220r and 1522r (Johnson, 1994b).

Small-subunit rRNA sequences of Bacillus and Paenibacillus reference strains were obtained from GenBank and the Ribosomal Database Project (Maidak et al., 1999). Sequences were aligned initially using the CLUSTAL $\mathrm{x}$ editor (Thompson et al., 1999). This alignment was refined manually, using the Genetic Data Environment Editor (Maidak et al., 1999). Because sequence positions corresponding to Escherichia coli 16S rRNA (Gutell, 1993) nucleotides 69-94 were highly heterogeneous and unalignable, they were excluded from the analyses.

Maximum-likelihood analysis was performed using fastDNAml (Olsen et al., 1994) with empirical base frequencies and an optimized transition/transversion ratio of $1 \cdot 3$. The tree of highest likelihood was found by repeated tree building $(100 \times)$ using random sequence input order, with global branch rearrangement of the final tree. Unweighted least squares distance matrix (Jukes-Cantor correction) and unweighted maximum-parsimony trees were inferred with PAUP 4.0b3a (D. Swofford, distributed by Sinauer Associates), using 100 rounds of random sequence addition order and optimized by tree-bisection-reconstruction branch swapping. Bootstrap analyses by maximum-likelihood and maximum-parismony methods were performed on 100 resampled datasets each. A dissimilarity matrix was calculated from the mean character differences for each pair of sequences by using PAUP $4.0 \mathrm{~b} 3 \mathrm{a}$.

DNA base composition. The $\mathrm{G}+\mathrm{C}$ content of the genomic DNA was estimated using the method described by Mesbah et al. (1989), with some modifications. The samples were analysed by HPLC (model SCL-10A; Shimadzu) equipped with a Supelcosil LC-18 column $(250 \times 4.6 \mathrm{~mm}$; particle size, $5 \mu \mathrm{m}$; Supelco) with $\mathrm{KH}_{2} \mathrm{PO}_{4}(49 \mathrm{mM}$, adjusted to $\mathrm{pH} 4 \cdot 0$ with $\left.\mathrm{H}_{3} \mathrm{PO}_{4}\right)$-methanol $\left(90: 10,1.5 \mathrm{ml} \mathrm{min}^{-1}\right)$ as the eluant, with detection at $280 \mathrm{~nm}$ using a Shimadzu SPD-10A UVvisible variable-wavelength detector.

DNA-DNA hybridization. The DNA preparations were sheared by two passages through a French press. DNADNA hybridization was done using the S1 nuclease method (Johnson, 1994a), with the modifications described by Song et al. (1998). The hybridization was performed at a reannealing temperature of $57^{\circ} \mathrm{C}$ based on the $\mathrm{G}+\mathrm{C}$ content of the DNA.

\section{RESULTS AND DISCUSSION}

\section{Morphological features of the PAH-degrading, spore- forming Paenibacillus isolates}

Two morphologically distinct groups of spore-formers were isolated from petroleum-hydrocarbon-contami-

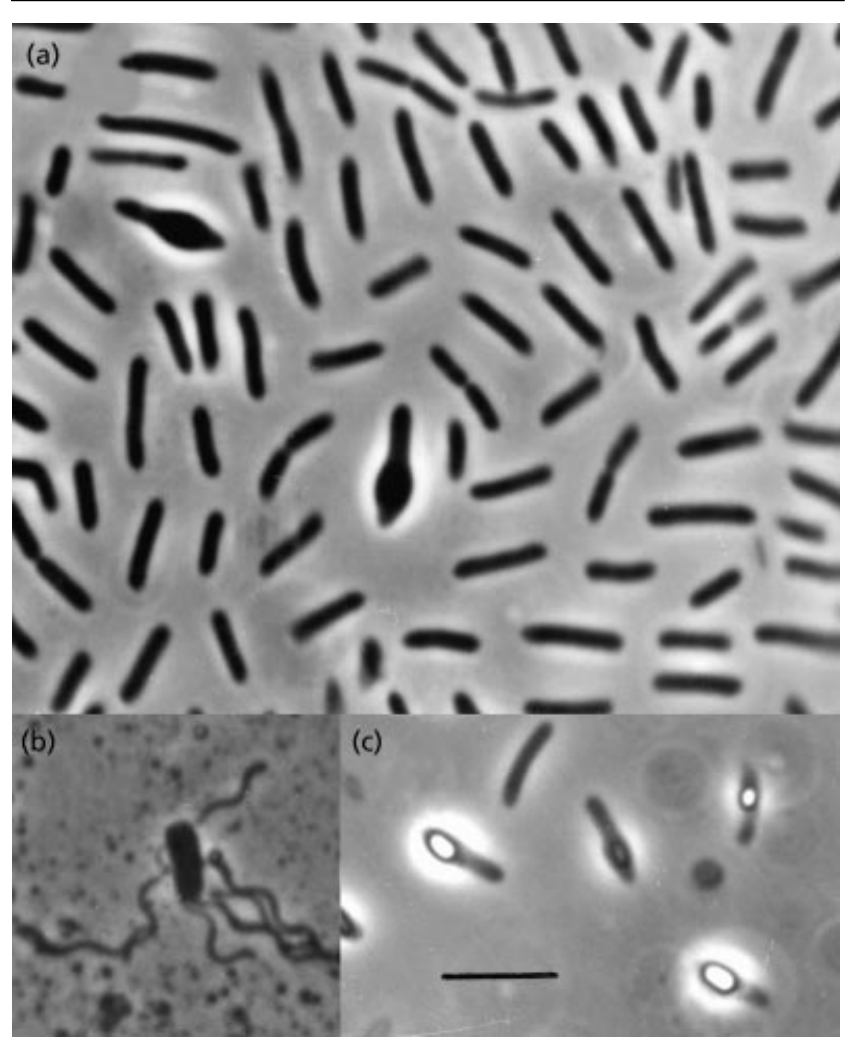

Fig. 1. Strain PR-N1 $1^{\top}$. (a) A crowded area of a wet mount showing that the cells are separated from one another because of the capsular material. (b) Peritrichous flagella stained by Leifson's method. (c) Spores in swollen sporangia. Bar, $5 \mu \mathrm{m}$. 
Table 2. Whole-cell fatty acid compositions (\%, w/w of total) of the PAH-degrading Paenibacillus isolates and several type species of the genera Paenibacillus, as determined by GC analysis of their methyl esters

\begin{tabular}{|c|c|c|c|c|c|c|c|c|c|c|c|c|}
\hline Species or isolate* & $\begin{array}{c}14: 0 \\
\text { iso }\end{array}$ & 14:0 & $\begin{array}{c}15: 0 \\
\text { iso }\end{array}$ & $\begin{array}{c}15: 0 \\
\text { anteiso }\end{array}$ & $15: 0$ & $\begin{array}{c}16: 1 \omega 7 c \\
\text { alcohol }\end{array}$ & $\begin{array}{c}16: 0 \\
\text { iso }\end{array}$ & $\begin{array}{l}16: 1 \\
\omega 11 c\end{array}$ & $16: 0$ & $\begin{array}{l}\text { iso } 17: 1 \\
\quad \omega 10 c\end{array}$ & $\begin{array}{c}17: 0 \\
\text { iso }\end{array}$ & $\begin{array}{c}17: 0 \\
\text { anteiso }\end{array}$ \\
\hline \multicolumn{13}{|l|}{ Mucoid } \\
\hline PR-N1 $1^{T}$ & $\mathrm{ND}$ & $2 \cdot 5$ & $5 \cdot 3$ & $51 \cdot 8$ & ND & ND & $5 \cdot 6$ & $9 \cdot 3$ & $14 \cdot 4$ & ND & $3 \cdot 2$ & $7 \cdot 9$ \\
\hline PR-N5 & ND & $3 \cdot 7$ & $4 \cdot 7$ & $47 \cdot 9$ & ND & ND & $4 \cdot 3$ & $16 \cdot 7$ & $13 \cdot 4$ & ND & $2 \cdot 8$ & 6.5 \\
\hline PS-N1 & $2 \cdot 3$ & $2 \cdot 8$ & $6 \cdot 0$ & $55 \cdot 0$ & 1.5 & ND & $5 \cdot 5$ & $9 \cdot 8$ & $9 \cdot 0$ & ND & 1.9 & $6 \cdot 3$ \\
\hline PS-N6 & 1.8 & $2 \cdot 8$ & $5 \cdot 3$ & $52 \cdot 9$ & 1.5 & 1.9 & 5.9 & $12 \cdot 0$ & $8 \cdot 5$ & ND & 1.7 & 5.8 \\
\hline SA-N1 & 1.9 & $2 \cdot 8$ & $5 \cdot 6$ & $49 \cdot 8$ & $2 \cdot 1$ & 1.5 & $5 \cdot 2$ & $12 \cdot 8$ & 8.9 & ND & $2 \cdot 9$ & 6.5 \\
\hline PR-N16 & $1 \cdot 3$ & $2 \cdot 7$ & 6.8 & $45 \cdot 4$ & 3.5 & $1 \cdot 0$ & $4 \cdot 7$ & $11 \cdot 6$ & $12 \cdot 7$ & ND & $4 \cdot 3$ & $6 \cdot 1$ \\
\hline \multicolumn{13}{|l|}{ Non-mucoid } \\
\hline DS-N2 & 3.7 & $1 \cdot 7$ & $13 \cdot 7$ & $50 \cdot 7$ & 0.9 & $2 \cdot 8$ & $7 \cdot 0$ & 5.7 & $4 \cdot 7$ & 1.0 & $3 \cdot 3$ & $4 \cdot 3$ \\
\hline JG-N2 & 3.9 & $1 \cdot 8$ & $14 \cdot 4$ & $49 \cdot 4$ & $0 \cdot 7$ & $3 \cdot 1$ & $8 \cdot 1$ & $5 \cdot 4$ & $4 \cdot 5$ & $1 \cdot 0$ & $3 \cdot 4$ & $3 \cdot 8$ \\
\hline PR-N13 & $2 \cdot 6$ & $1 \cdot 4$ & $10 \cdot 1$ & $52 \cdot 3$ & $1 \cdot 0$ & 1.7 & $7 \cdot 9$ & $4 \cdot 5$ & $7 \cdot 0$ & 0.9 & $4 \cdot 3$ & $5 \cdot 7$ \\
\hline PR-N19 & $2 \cdot 9$ & $1 \cdot 6$ & $11 \cdot 0$ & $50 \cdot 7$ & $1 \cdot 0$ & $2 \cdot 3$ & $8 \cdot 3$ & $5 \cdot 3$ & $6 \cdot 7$ & 0.9 & $3 \cdot 4$ & $5 \cdot 1$ \\
\hline PR-N21 & $3 \cdot 0$ & $1 \cdot 3$ & $13 \cdot 8$ & $53 \cdot 9$ & ND & $2 \cdot 7$ & $7 \cdot 3$ & $4 \cdot 3$ & $4 \cdot 3$ & $1 \cdot 1$ & $3 \cdot 5$ & $4 \cdot 7$ \\
\hline PR-P1 & $3 \cdot 4$ & $1 \cdot 7$ & $11 \cdot 7$ & $54 \cdot 0$ & $0 \cdot 8$ & $3 \cdot 2$ & $6 \cdot 6$ & $6 \cdot 1$ & $4 \cdot 2$ & ND & $3 \cdot 0$ & $4 \cdot 4$ \\
\hline PR-P9 & $2 \cdot 9$ & $1 \cdot 7$ & $12 \cdot 7$ & $46 \cdot 3$ & 1.0 & $3 \cdot 1$ & $7 \cdot 5$ & $7 \cdot 1$ & $5 \cdot 6$ & 1.4 & $4 \cdot 2$ & $5 \cdot 1$ \\
\hline P. validus ATCC $43897^{\mathrm{T}}$ & $2 \cdot 7$ & $1 \cdot 8$ & $13 \cdot 2$ & $48 \cdot 0$ & $0 \cdot 9$ & $2 \cdot 2$ & $6 \cdot 8$ & $6 \cdot 9$ & $6 \cdot 4$ & $1 \cdot 7$ & $4 \cdot 3$ & $5 \cdot 3$ \\
\hline P. polymyxa ATCC $842^{\mathrm{T}}$ & $2 \cdot 9$ & $3 \cdot 4$ & 6.8 & $48 \cdot 6$ & ND & ND & $11 \cdot 0$ & 1.8 & $15 \cdot 9$ & ND & $3 \cdot 7$ & $5 \cdot 8$ \\
\hline P. pabuli ATCC $43899^{\mathrm{T}}$ & $3 \cdot 5$ & $3 \cdot 7$ & $10 \cdot 9$ & $48 \cdot 6$ & ND & ND & $5 \cdot 7$ & $6 \cdot 3$ & $13 \cdot 2$ & ND & $4 \cdot 9$ & $3 \cdot 2$ \\
\hline P. alvei ATCC $6344^{\mathrm{T}}$ & $1 \cdot 3$ & $2 \cdot 2$ & $8 \cdot 7$ & $51 \cdot 4$ & $5 \cdot 2$ & $1 \cdot 1$ & $6 \cdot 0$ & 3.7 & $8 \cdot 7$ & $2 \cdot 9$ & $3 \cdot 1$ & $6 \cdot 7$ \\
\hline
\end{tabular}

ND, Not detected.

* Mucoid and non-mucoid refer to the colony morphologies of the PAH-degrading Paenibacillus isolates. The mucoid strains represent the proposed Paenibacillus naphthalenovorans sp. nov., and the non-mucoid isolates are members of $P$. validus.

nated estuarine sediment and salt marsh rhizospheres by aerobic enrichment using either naphthalene, phenanthrene or biphenyl as the sole carbon source (Daane et al., 2001). Strains PR-N1 ${ }^{\mathrm{T}}$, PR-N5, PR-N16, PS$\mathrm{N} 1$, PS-N6 and SA-N1 formed white, translucent, mucoid colonies when grown on solid medium. In contrast, a non-mucoid, mottled colony morphology was created by the remaining isolates (Table 1). Fig. 1 shows mucoid strain PR-N1 ${ }^{\mathrm{T}}$ observed by phasecontrast microscopy. Observation of high-density areas shows that the cells were separated from one another by capsular material (Fig. 1a). A cell with peritrichous flagellation is depicted in Fig. 1b. Spores in swollen sporangia are shown in Fig. 1c.

\section{FAME analysis}

FAME analysis suggested that the two morphological groups of PAH-degrading isolates were members of the genus Paenibacillus (Daane et al., 2001). The nonmucoid isolates were identified as $P$. validus, having a strong match with the MIDI database (similarity index $\geqslant 0 \cdot 70$ ). In contrast, the mucoid isolates were only distantly related to either $P$. validus, $P$. pabuli or $P$. alvei. Table 2 lists the fatty acid compositions of the mucoid and non-mucoid isolates, and the type strains of several Paenibacillus species. The predominant cellular fatty acid for all of the tested isolates and type strains was 15:0 anteiso, comprising $45-55 \%$ of the total; this is indicative of the genus Paenibacillus (Ash et al., 1993; Shida et al., 1997a). However, the mucoid isolates differ from the closely related $P$. validus type strain and non-mucoid isolates in the relative abundance of several fatty acids $(15: 0$ iso, $16: 1 \omega 11 c, 16: 0$

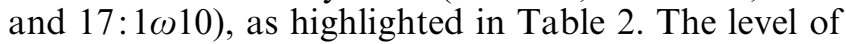
$15: 0$ iso in the mucoid group was $5.6 \pm 0.7 \%$, as opposed to $13 \cdot 2 \%$ and $12 \cdot 5 \pm 1.6 \%$ for $P$. validus and the non-mucoid group, respectively. Similarly, the levels of $16: 1 \omega 11 \mathrm{c}$ and $16: 0$ were $12 \cdot 0 \pm 2 \cdot 6 \%$ and $11 \cdot 2 \pm 2.6 \%$, respectively, in the mucoid group, as opposed to $6.9 \%$ and $6.4 \%$, respectively, for P. validus. In addition, the unsaturated acid, iso $17: 1 \omega 10$, was not detected in any of the mucoid isolates; the levels were $1.7 \%$ and $0.9 \pm 0.4 \%$ in the type strain of $P$. validus and the non-mucoid group, respectively.

A pairwise comparison Euclidean distance (ED) dendrogram based on whole-cell fatty acid compositions of the sediment and rhizosphere Paenibacillus isolates and ATCC type strains (data not shown) indicated that members of the mucoid-colony-morphology group form a tight cluster $(\mathrm{ED} \leqslant 8.0)$ and are distantly related to their most closely identified Paenibacillus species $(\mathrm{ED}=13 \cdot 0)$. In contrast, close clustering of the members of the non-mucoid-morphology group suggested conspecificity of these isolates with respect to the $P$. validus type strain $(\mathrm{ED} \leqslant 5)$. These results indicate that the members of the mucoid 
cluster form a distinct group and may represent a new Paenibacillus species.

\section{Phenotypic characterization}

The mucoid, non-mucoid groups and type strains of selected Paenibacillus were differentiated phenotypically using the API $20 \mathrm{E}$ and $50 \mathrm{CH}$ test systems (Table 3). Acetoin (Voges-Proskauer test) was produced by the mucoid isolates and the $P$. polymyxa type strain, but not by the other organisms. The mucoid isolates were all unable to hydrolyse aesculin or produce acid from glycerol, D-ribose, D-raffinose or starch, unlike the non-mucoid isolates (D-raffinose variable) and the Paenibacillus type strains. Moreover, the mucoid isolates and the $P$. alvei type strain did not produce acid from D-xylose or glycogen; all other strains tested were positive for this trait. Lastly, while the mucoid isolates did not ferment inositol, the nonmucoid isolates and the $P$. validus type strain did. Other differences between the two isolate groups and the type strains are shown in Table 3.

Growth of the PAH-degrading strains on a variety of aromatic substrates is summarized in Table 4. The non-mucoid isolates utilized a greater number of aromatic substrates than the mucoid isolates. Of the substrates tested, gentisate, phthalate and $o$-hydroxybenzoate were not suitable growth substrates for either groups. Aromatics utilized by both groups included naphthalene, $p$-hydroxybenzoate and benzoate. Only the mucoid group utilized $m$-hydroxybenzoate. In contrast, phenanthrene and biphenyl were growth substrates only for the non-mucoid isolates, and not for the mucoid group.

Utilization of aromatic substrates by members of the genus Paenibacillus has been reported previously. Pichinoty et al. (1986) described Bacillus gordonae sp. nov. (emended as $P$. validus by Heyndrickx et al., 1995), which utilized $p$-hydroxybenzoate, phthalate, isophthalate, protocatechuate, trimellitate, quinate, phenol, $p$-cresol and naphthalene as sole carbon sources. Recently, Meyer et al. (1999) reported the isolation of a PAH-degrading micro-organism, tentatively identified as a Paenibacillus sp., from tar oilcontaminated soil. In the present study, we found that naphthalene was a suitable growth substrate for $P$. validus but not $P$. alvei, $P$. pabuli or $P$. polymyxa.

\section{Phylogenetic analyses}

A dissimilarity matrix (not shown) of the rRNA sequences was calculated. Intragroup values ranged from 0.001 to 0.007 for the mucoid group, and from 0.001 to 0.012 for the non-mucoid group (which included $P$. validus). Intergroup values of 0.029-0.093 were measured between the mucoid or non-mucoid groups and the recognized Paenibacillus spp. These data suggested that the mucoid group was a distinct Paenibacillus species. Moreover, the non-mucoid isolates were shown to be strains of $P$. validus.
Detailed analyses using several inference methods generated trees that were congruent in topology for well-supported ( $>70 \%$ by bootstrap analyses) branches (Fig. 2). The distinct grouping of the mucoid strains separately from all named Paenibacillus spp. is strongly supported $(100 \%$ by maximum-likelihood and maximum-parsimony methods). Phylogenetic relationships between isolates within this group, however, were unresolved. Strong support was also found for a close relationship between the $P$. validus and the non-mucoid strains (DS-N1, PR-P1, PR-P9 and PRN19). These two groups cluster together specifically, to the exclusion of all other Paenibacillus spp., with high bootstrap support $(97 / 99 \%)$. These results support the conclusion that the mucoid isolates represent a distinct group of Paenibacillus that is closely related to $P$. validus. In addition, the $\mathrm{PAH}-\mathrm{deg}$ rading isolates, P. validus, Paenibacillus chrondrotinus, Paenibacillus alginolyticus and $P$. larvae form a coherent group to the exclusion of all other Paenibacillus species, with moderate $(81 / 74 \%)$ bootstrap support.

\section{DNA base composition of Paenibacillus isolates}

The $\mathrm{G}+\mathrm{C}$ content for the genus Paenibacillus ranges broadly from $39 \mathrm{~mol} \%$ (reported for Paenibacillus macquariensis; Claus \& Berkeley, 1986) to $55 \mathrm{~mol} \%$ (for Paenibacillus dendritiformis; Tcherpakov et al., 1999). The $\mathrm{G}+\mathrm{C}$ content of the genomic DNA of members of the mucoid group and several isolates from the non-mucoid group is shown in Table 5. The results for both the mucoid and non-mucoid groups fall within the range for the genus Paenibacillus. The mean ( \pm standard deviation) $\mathrm{G}+\mathrm{C}$ content for the mucoid group was $48.8 \pm 1.9 \mathrm{~mol} \%$. This value is close to that found for $P$. validus ATCC $43897^{\mathrm{T}}$, but less than that of the non-mucoid group $(50 \cdot 6 \pm 2 \cdot 2 \mathrm{~mol} \%)$.

\section{DNA hybridization experiments}

Table 5 also summarizes the DNA similarity values obtained by hybridization using the S1 nuclease methodology. The similarity between reference PR$\mathrm{N}^{\mathrm{T}}$ and other members of the mucoid group was high (71-97\%), with the exception of strain SA-N1 (46\%). A low similarity value of $6 \%$ was observed between strain $\mathrm{PR}-\mathrm{N} 1^{\mathrm{T}}$ and the $P$. validus type strain. The reciprocal reaction, using $P$. validus as the reference DNA, revealed a low level of similarity to strain PR$\mathrm{N}^{\mathrm{T}}(13 \%)$, and high levels of similarity to members of the non-mucoid group. These results show that the members of the mucoid group comprise a taxon distinct from the non-mucoid group and $P$. validus. DNA similarity analysis confirmed the identification of the non-mucoid PAH-degrading isolates as members of $P$. validus.

In summary, on the basis of the morphological, phenotypic and molecular data, the naphthalenedegrading mucoid isolates can be classified into a new species of Paenibacillus, for which we propose the name $P$. naphthalenovorans. 
Table 3. Phenotypic characteristics of PAH-degrading strains isolated from sediment and rhizospheres, and closely related Paenibacillus strains

All strains were motile, catalase-positive, grew at 30 and $37{ }^{\circ} \mathrm{C}$, did not grow at 5 or $55^{\circ} \mathrm{C}$, and did not grow with $5 \% \mathrm{NaCl}$. All isolates were negative for arginine dihydrolase, lysine decarboxylase, ornithine decarboxylase, $\mathrm{H}_{2} \mathrm{~S}$ production and tryptophan deaminase. All isolates produced acid from maltose, saccharose and trehalose, but none produced acid from erythritol, L-xylose, sorbitol, methyl $\alpha$-D-mannoside, D-lyxose, D-fucose, L-arabitol, 2-keto-gluconate and 5-keto-gluconate.,$+ 90 \%$ of strains reacted positively; $\mathrm{v}$, less than $90 \%$ of strains reacted positively or negatively; - , $90 \%$ of strains reacted negatively.

\begin{tabular}{|c|c|c|c|c|c|c|}
\hline Characteristic & $\begin{array}{c}P . \text { alvei ATCC } \\
6344^{\mathrm{T}}\end{array}$ & $\begin{array}{c}P . \text { pabuli } \\
{\text { ATCC } 43899^{\mathrm{T}}}^{2}\end{array}$ & $\begin{array}{l}\text { P. polymyxa } \\
\text { ATCC } 842^{\mathrm{T}}\end{array}$ & $\begin{array}{c}P . \text { validus } \\
\text { ATCC } 43897^{\mathrm{T}}\end{array}$ & $\begin{array}{l}\text { Group } 1 \text { (mucoid) } \\
\quad(n=6)\end{array}$ & $\begin{array}{c}\text { Group } 2(\text { non- } \\
\text { mucoid) }(n=6)\end{array}$ \\
\hline Anaerobic growth & + & - & + & - & - & - \\
\hline Growth with $3 \% \mathrm{NaCl}$ & - & + & + & - & $\mathrm{v}$ & - \\
\hline Growth at $10^{\circ} \mathrm{C}$ & - & + & - & - & - & - \\
\hline \multicolumn{7}{|l|}{ Hydrolysis of: } \\
\hline Casein & + & + & + & - & - & - \\
\hline Starch & + & + & + & + & $\mathrm{v}$ & + \\
\hline \multicolumn{7}{|l|}{ API $20 \mathrm{E}$ tests } \\
\hline ONPG & + & + & + & - & - & - \\
\hline Citrate & - & - & - & - & $\mathrm{v}$ & - \\
\hline Urease & + & - & - & + & + & + \\
\hline Indole production & + & - & - & - & - & - \\
\hline Voges-Proskauer & - & - & + & - & + & - \\
\hline Gelatin hydrolysis & + & - & + & - & - & - \\
\hline Nitrate reduction & - & + & - & - & $\mathrm{v}$ & - \\
\hline \multicolumn{7}{|l|}{ API 50CH tests } \\
\hline Aesculin hydrolysis & + & + & + & + & - & + \\
\hline \multicolumn{7}{|l|}{ Acid produced from: } \\
\hline Glycerol & + & + & + & + & - & + \\
\hline D-Arabinose & - & + & - & - & - & - \\
\hline L-Arabinose & - & + & + & - & - & - \\
\hline Ribose & + & + & + & + & - & + \\
\hline D-Xylose & - & + & + & + & - & + \\
\hline Adonitol & + & - & - & - & - & - \\
\hline Methyl $\beta$-xyloside & - & + & + & - & - & - \\
\hline Galactose & - & + & + & + & + & + \\
\hline D-Glucose & - & + & + & + & + & + \\
\hline D-Fructose & - & + & + & + & $\mathrm{v}$ & + \\
\hline D-Mannose & - & + & + & + & + & $\mathrm{v}$ \\
\hline L-Sorbose & - & - & - & - & $\mathrm{v}$ & - \\
\hline Rhamnose & - & + & - & - & - & - \\
\hline Dulcitol & - & - & - & - & - & + \\
\hline Inositol & - & + & - & + & - & + \\
\hline Mannitol & - & + & + & + & + & + \\
\hline Methyl $\alpha$-D-glucoside & - & + & + & + & $\mathrm{v}$ & + \\
\hline$N$-Acetylglucosamine & + & + & - & - & - & - \\
\hline Amygdalin & - & + & + & - & - & - \\
\hline Arbutin & + & + & + & - & - & - \\
\hline Salicin & - & + & + & - & - & - \\
\hline Cellobiose & - & + & + & - & - & $\mathrm{v}$ \\
\hline Lactose & - & + & + & - & - & - \\
\hline Melibose & + & + & + & + & $\mathrm{v}$ & $\mathrm{v}$ \\
\hline Inulin & - & + & + & - & - & - \\
\hline Melezitose & - & + & + & - & - & - \\
\hline D-Raffinose & + & + & + & + & - & $\mathrm{v}$ \\
\hline Starch & + & + & + & + & - & + \\
\hline Glycogen & - & + & + & + & - & + \\
\hline Xylitol & - & - & - & - & $\mathrm{v}$ & - \\
\hline
\end{tabular}


Table 3 (cont.)

\begin{tabular}{|c|c|c|c|c|c|c|}
\hline Characteristic & $\begin{array}{c}P . a l v e i \text { ATCC } \\
6344^{T}\end{array}$ & $\begin{array}{c}P . \text { pabuli } \\
\text { ATCC 43899 }\end{array}$ & $\begin{array}{l}\text { P. polymyxa } \\
\text { ATCC } 842^{\mathrm{T}}\end{array}$ & $\begin{array}{c}\text { P. validus } \\
\text { ATCC } 43897^{\mathrm{T}}\end{array}$ & $\begin{array}{l}\text { Group } 1 \text { (mucoid) } \\
\qquad(n=6)\end{array}$ & $\begin{array}{c}\text { Group } 2 \text { (non- } \\
\text { mucoid) }(n=6)\end{array}$ \\
\hline$\beta$-Gentiobiose & + & + & + & - & - & $\mathrm{V}$ \\
\hline D-Turanose & - & + & + & + & $\mathrm{V}$ & + \\
\hline D-Tagatose & - & - & - & - & - & $\mathrm{V}$ \\
\hline L-Fucose & - & + & - & - & - & - \\
\hline D-Arabitol & - & - & - & - & - & $\mathrm{V}$ \\
\hline Gluconate & - & + & - & - & - & - \\
\hline
\end{tabular}

Table 4. Growth of isolates from sediment and rhizospheres on aromatic substrates

Positive results were obtained for all strains for the utilization of naphthalene and benzoate.

Negative results were obtained with all strains for the utilization of phthalate, gentisate and $o$ hydroxybenzoate. + , Growth of the isolate after 1 week of incubation at $30^{\circ} \mathrm{C}$; - , no growth; $\mathrm{ND}$, not determined.

\begin{tabular}{|c|c|c|c|c|c|c|}
\hline \multirow[t]{3}{*}{ Substrate* } & \multicolumn{6}{|c|}{ PAH-degrading Paenibacillus isolates $\dagger$} \\
\hline & \multicolumn{2}{|c|}{ Mucoid colony morphology } & \multicolumn{4}{|c|}{ Non-mucoid colony morphology } \\
\hline & PS-N1 & PR-N1 ${ }^{\mathrm{T}}$ & PR-N5 & PR-N4 & PR-P1 & PR-B2 \\
\hline Phenanthrene & - & - & - & + & + & - \\
\hline Biphenyl & - & - & - & + & + & + \\
\hline$m$-Hydroxybenzoate & - & + & + & - & - & ND \\
\hline$p$-Hydroxybenzoate & - & + & + & + & + & ND \\
\hline
\end{tabular}

* Substrate concentrations: naphthalene and biphenyl were added as crystals in the Petri-dish lid; phenanthrene $\left(1 \mathrm{mg} \mathrm{ml}^{-1}\right)$ was added as an agarose overlayer; organic acids were added to media at 5-10 mM.

$\dagger$ Mucoid isolates represent $P$. naphthalenovorans sp. nov.; non-mucoid strains were identified as Paenibacillus validus.

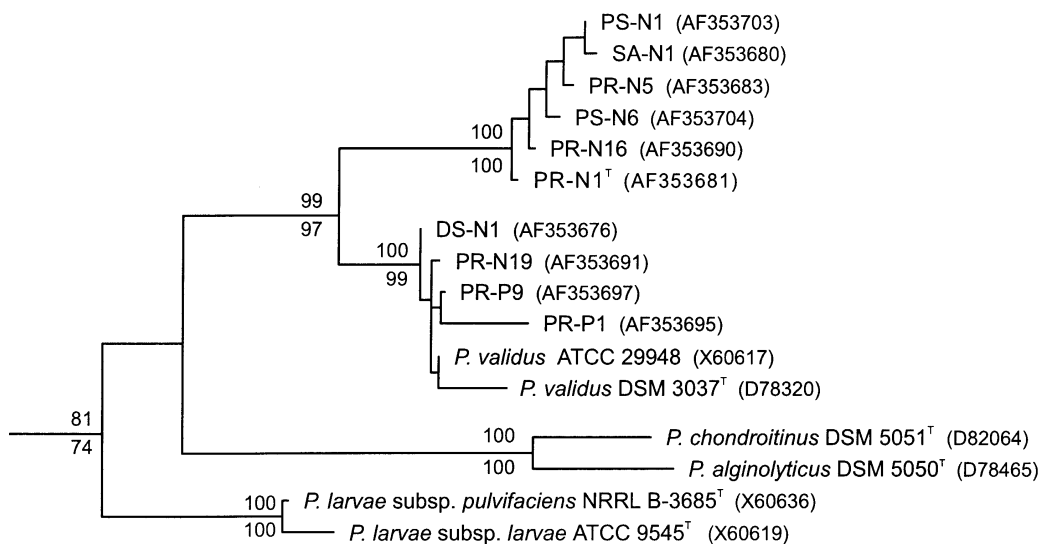

0.010

\begin{abstract}
Fig. 2. Phylogenetic analysis of the polyaromatic hydrocarbon-degrading Paenibacillus isolates. The tree was inferred by maximumlikelihood analysis of homologous nucleotide positions of $16 \mathrm{~S}$ rDNA sequence from each organism. An additional 21 sequences, representing the Paenibacillus type strains for which 16S rRNA sequences are available, were included in the analysis (not shown) and branched as an outgroup to the sequences shown. Numbers indicate percentages of bootstrap resamplings that support branches for maximum-likelihood/ maximum-parsimony analyses. Bootstrap results are reported only for those branches that attained $>70 \%$ support with at least one method.
\end{abstract}

\section{Description of Paenibacillus naphthalenovorans sp. nov.}

Paenibacillus naphthalenovorans (naph.tha.le.no. vo'rans. L. neut. n. naphthalene from Persian neft naphtha; L. v. vorare to devour; N.L. part. adj. naphthalenovorans naphthalene-devouring).

Cells are rod-shaped and are $0.8 \mu \mathrm{m}$ wide by 2.8 $4.0 \mu \mathrm{m}$ long, are motile by peritrichous flagella, and are 
Table 5. $\mathrm{G}+\mathrm{C}$ content and DNA binding data for PAHdegrading Paenibacillus isolates and $P$. validus

\begin{tabular}{|lccc|}
\hline Strain & mol \%G + C & \multicolumn{2}{c|}{ DNA similarity (\%) with: } \\
\cline { 3 - 4 } & & & PR-N1 \\
& & & P. validus \\
\hline P. validus ATCC & $48 \cdot 7$ & $6 \cdot 0$ & 100 \\
$43897^{T}$ & & & \\
Mucoid & & & \\
PR-N1 & $46 \cdot 6$ & 100 & $13 \cdot 2$ \\
PS-N1 & $51 \cdot 5$ & $97 \cdot 0$ & ND \\
PR-N5 & $50 \cdot 1$ & $87 \cdot 6$ & ND \\
PR-N16 & $49 \cdot 9$ & $87 \cdot 3$ & ND \\
PS-N6 & $47 \cdot 7$ & $70 \cdot 9$ & ND \\
SA-N1 & $47 \cdot 2$ & $45 \cdot 5$ & ND \\
Non-mucoid & & & \\
PR-P1 & $50 \cdot 1$ & ND & $72 \cdot 2$ \\
PR-N19 & $53 \cdot 0$ & ND & $79 \cdot 0$ \\
DS-N1 & $48 \cdot 8$ & ND & ND \\
\hline
\end{tabular}

ND, Not determined.

Gram-positive. Ellipsoidal spores are formed in swelling sporangia. Optimum growth occurs between 30 and $37^{\circ} \mathrm{C}$, but does not occur at either 10 or $55^{\circ} \mathrm{C}$. Does not grow in the presence of $5 \%(\mathrm{w} / \mathrm{v}) \mathrm{NaCl}$, and growth with $3 \%(\mathrm{w} / \mathrm{v}) \mathrm{NaCl}$ is variable. Forms white, translucent, mucoid colonies when grown on solid media. Strictly aerobic. Catalase-positive. Casein hydrolysis is negative; starch hydrolysis is variable. Gelatin and ONPG are not hydrolysed, and arginine dihydrolase, lysine decarboxylase, ornithine decarboxylase, tryptophan deaminase, hydrogen sulfide and indole are not produced. Citrate utilization and nitrate reduction are variable. Urease and acetoin are produced. Acid, but no gas, is produced from galactose, D-glucose, maltose, mannitol, D-mannose, saccharose and trehalose. Strain variation is observed for fermentation of D-fructose, melibose, methyl $\alpha$-Dglucoside, L-sorbose, D-turanose and xylitol. Neither acid nor gas is produced from $N$-acetylglucosamine, adonitol, starch, amygdalin, D-arabinose, L-arabinose, D-arabitol, L-arabitol, arbutin, cellobiose, dulcitol, erythritol, D-fucose, L-fucose, $\beta$-gentiobiose, gluconate, glycerol, glycogen, inositol, inulin, 2-ketogluconate, 5-keto-gluconate, lactose, D-lyxose, melezitose, methyl $\alpha$-D-mannoside, methyl $\beta$-xyloside, D-raffinose, L-rhamnose, D-ribose, salicin, sorbitol, D-tagatose, D-xylose and L-xylose. The predominant cellular fatty acids are 14:0 (2.9\%), 15:0 iso $(5 \cdot 6 \%)$, $15: 0$ anteiso $(50.5 \%), 16: 0$ iso $(5.2 \%), 16: 1 \omega 11 c$ $(12.0 \%), 16: 0(11.2 \%), 17: 0$ iso $(2 \cdot 8 \%)$ and $17: 0$ anteiso $(6.5 \%)$. The mean $\mathrm{G}+\mathrm{C}$ content of the DNA is $49 \mathrm{~mol} \%$, as determined by HPLC. The habitats are estuarine sediments and salt marsh rhizospheres. Isolate PR-N $1{ }^{\mathrm{T}}$ is the type strain (= ATCC BAA- $206^{\mathrm{T}}$ $\left.=\operatorname{DSM} 14203^{\mathrm{T}}\right)$. The description of this strain is essentially identical to that of the species. This strain does not grow in the presence of $3 \% \mathrm{NaCl}$, is negative for starch hydrolysis, and does not utilize citrate or reduce nitrate. It produces acid, but not gas, from D-fructose, methyl $\alpha$-D-glucoside, L-sorbose and Dturanose. No acid or gas is produced from melibose or xylitol.

\section{ACKNOWLEDGEMENTS}

This work was supported, in part, by a grant from the New Jersey Commission on Science and Technology. We wish to thank Jean-Alex Molina for assistance with French translations. We also thank Quinn Im, Michael Murillo, Lisa Newman and Bongkeun Song for helpful discussions and technical assistance. We acknowledge Cheryl Kuske for helpful suggestions regarding the manuscript and for the use of laboratory resources, computers and software for phylogenetic analyses.

\section{REFERENCES}

Alexander, B. \& Priest, F. G. (1989). Bacillus glucanolyticus, a new species that degrades a variety of $\beta$-glucans. Int J Syst Bacteriol 39, 112-115.

Ash, C., Farrow, J. A. E., Wallbanks, S. \& Collins, M. D. (1991). Phylogenetic heterogeneity of the genus Bacillus revealed by comparative analysis of small-subunit-ribosomal RNA sequences. Lett Appl Microbiol 13, 202-206.

Ash, C., Priest, F. G. \& Collins, M. D. (1993). Molecular identification of rRNA group 3 bacilli (Ash, Farrow, Wallbanks and Collins) using a PCR probe test. Proposal for the creation of a new genus Paenibacillus. Antonie Leeuwenhoek 64, 253-260.

Claus, D. \& Berkeley, R. C. W. (1986). Genus Bacillus Cohn 1872. In Bergey's Manual of Systematic Bacteriology, vol. 2, pp. 1105-1139. Edited by P. H. A. Sneath, N. S. Mair, M. E. Sharpe \& J. G. Holt. Baltimore: Williams \& Wilkins.

Daane, L. L., Harjono, I., Zylstra, G. J. \& Häggblom, M. M. (2001). Isolation and characterization of polycyclic aromatic hydrocarbon-degrading bacteria associated with the rhizosphere of salt marsh plants. Appl Environ Microbiol 67, 2683-2691.

Gutell, R. R. (1993). Collection of small subunit (16S- and 16S-like) ribosomal RNA structures. Nucleic Acids Res 21, 3051-3054.

Heyndrickx, M., Vandemeulebroecke, K., Scheldeman, P. \& 7 other authors (1995). Paenibacillus (formerly Bacillus) gordonae (Pichinoty et al. 1986) Ash et al. 1994 is a later subjective synonym of Paenibacillus (formerly Bacillus) validus (Nakamura 1984) Ash et al. 1994: emended description of P. validus. Int J Syst Bacteriol 45, 661-669.

Johnson, J. L. (1994a). Similarity analysis of DNAs. In Methods for General and Molecular Bacteriology, pp. 655-682. Edited by P. Gerhardt, R. G. E. Murray, W. A. Wood \& N. R. Krieg. Washington, DC: American Society for Microbiology.

Johnson, J. L. (1994b). Similarity analysis of rRNAs. In Methods for General and Molecular Bacteriology, pp. 683-700. Edited by P. Gerhardt, R. G. E. Murray, W. A. Wood \& N. R. Krieg. Washington, DC: American Society for Microbiology.

Kanzawa, Y., Harada, A., Takeuchi, M., Yokota, A. \& Harada, T. (1995). Bacillus curdlanolyticus sp. nov. and Bacillus kobensis sp. nov., which hydrolyze resistant curdlan. Int J Syst Bacteriol 45, 515-521.

Leifson, E. (1951). Staining, shape, and arrangement of bacterial flagella. J Bacteriol 62, 377-389. 
Logan, N. A. \& Berkeley, R. C. W. (1984). Identification of Bacillus strains using the API system. J Gen Microbiol 130, 1871-1882.

Maidak, B. L., Cole, J. R., Parker, C. T. \& 11 other authors (1999). A new version of the RDP (Ribosomal Database Project). Nucleic Acids Res 27, 171-173.

Mesbah, M., Premachandran, U. \& Whitman, W. B. (1989). Precise measurement of the $\mathrm{G}+\mathrm{C}$ content of deoxyribonucleic acid by high-performance liquid chromatography. Int J Syst Bacteriol 39, 159-167.

Meyer, S., Moser, R., Neef, A., Stahl, U. \& Kämpfer, P. (1999). Differential detection of key enzymes of polyaromatichydrocarbon-degrading bacteria using PCR and gene probes. Microbiology 145, 1731-1741.

Montefusco, A., Nakamura, L. K. \& Labeda, D. P. (1993). Bacillus peoriae sp. nov. Int J Syst Bacteriol 43, 388-390.

Nakamura, L. K. (1984). Bacillus pulvifaciens sp. nov., nom. rev. Int J Syst Bacteriol 34, 410-413.

Nakamura, L. K. (1987). Bacillus alginolyticus sp. nov. and Bacillus chondroitinus sp. nov., two alginate-degrading species. Int J Syst Bacteriol 37, 284-286.

Olsen, G. J., Matsuda, H., Hagstrom, R. \& Overbeek, R. (1994). fastDNAml: a tool for construction of phylogenetic trees of DNA sequences using maximum likelihood. CABIOS 10, 41-48.

Pichinoty, F., Waterbury, J. B., Mandel, M. \& Asselineau, J. (1986). Bacillus gordonae sp. nov., une nouvelle espèce appartenant au second groupe morphologique, dégrandant divers composés aromatiques. Ann Inst Pasteur/Microbiol (Paris) 137A, 65-78.

Seldin, L., van Elsas, J. D. \& Penido, E. G. C. (1984). Bacillus azotofixans sp. nov., a nitrogen-fixing species from Brazilian soils and grass roots. Int $J$ Syst Bacteriol 34, 451-456.

Shida, O., Takagi, H., Kadowaki, K., Nakamura, L. K. \& Komagata, K. (1997a). Transfer of Bacillus alginolyticus, Bacillus chondroitinus, Bacillus curdlanolyticus, Bacillus glucanolyticus, Bacillus kobensis, and Bacillus thiaminolyticus to the genus Paenibacillus and emended description of the genus Paenibacillus. Int J Syst Bacteriol 47, 289-298.

Shida, O., Takagi, H., Kadowaki, K., Nakamura, L. K. \& Komagata, K. (1997b). Emended description of Paenibacillus amylolyticus and description of Paenibacillus illinoisensis sp. nov. and Paenibacillus chibensis sp. nov. Int J Syst Bacteriol 47, 299-306.

Smibert, R. M. \& Krieg, N. R. (1994). Phenotypic characterization. In Methods for General and Molecular Bacteriology, pp. 607-654. Edited by P. Gerhardt, R. G. E. Murray, W. A. Wood \& N. R. Krieg. Washington, DC: American Society for Microbiology.

Song, B., Young, L. Y. \& Palleroni, N. J. (1998). Identification of denitrifier strain $\mathrm{T} 1$ as Thauera aromatica and proposal for emendation of the genus Thauera definition. Int J Syst Bacteriol 48, 889-894.

Stanier, R. Y., Palleroni, N. J. \& Doudoroff, M. (1966). The aerobic pseudomonads: a taxonomic study. J Gen Microbiol 43, 159-271.

Tcherpakov, M., Ben-Jacob, E. \& Gutnick, D. L. (1999). Paenibacillus dendritiformis sp. nov., proposal for a new patternforming species and its localization within a phylogenetic cluster. Int J Syst Bacteriol 49, 239-246.

Thompson, J. D., Gibson, T. J., Plewniak, F., Jeanmougin, F. \& Higgins, D. G. (1999). The CLUSTAL X windows interface: flexible strategies for multiple sequence alignment aided by quality analysis tools. Nucleic Acids Res 24, 4876-4882.

Wilson, K. (1994). Preparation of genomic DNA from bacteria. In Current Protocols in Molecular Biology, vol. 1, pp. 2.4.1-2.4.5. Edited by F. M. Ausubel, R. Brent, R. E. Kingston, D. D. Moore, J. G. Seidman, J. A. Smith \& K. Struhl. New York: Wiley.

Yoon, J.-H., Yim, D. K., Lee, J.-S., Shin, K.-S., Sato, H. H., Lee, S. T., Park, Y. K. \& Park, Y.-H. (1998). Paenibacillus campinasensis sp. nov., a cyclodextrin-producing bacterium isolated in Brazil. Int J Syst Bacteriol 48, 833-837. 